\title{
Structure of bacterial, archaeal and microeukaryotic communities of upper sediment in Lake Vorota, Pole of Cold (Yakutia)
}

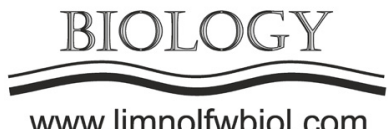

www.limnolfwbiol.com

\author{
Bashenkhaeva M.V. ${ }^{1 *}$, Zakharova Yu.R. ${ }^{1}$, Kopyrina L.I. ${ }^{2}$, Petrova D.P. ${ }^{1}$, \\ Galachyants Yu.P. ${ }^{1}$, Likhoshway Ye.V. ${ }^{1}$
}

${ }^{1}$ Limnological Institute, Siberian Branch of the Russian Academy of Sciences, Ulan-Batorskaya Str., 3, Irkutsk, 664033, Russia

${ }^{2}$ Institute for Biological Problems of Cryolithozone, Siberian Branch of Russian Academy of Sciences, 41 Lenin Ave., Yakutsk, 677980, Russia

\begin{abstract}
Upper layer of the bottom sediment is important as an area where freshly deposited sediment is remineralized. In this work we have described structure and diversity of bacterial, archaeal and microeukaryotic communities from upper sediment of Lake Vorota (Yakutia). According to highthroughput sequencing of $16 \mathrm{~S}$ fragment, most common bacteria are Cyanobacteria, Deltaproteobacteria, Bacteroidota and Desulfobacteriota; archaeal community is dominated by Halobacteriota. Analysis of 18S sequences from microscopic eukaryotes has revealed the predominance of Diatomea.
\end{abstract}

Keywords: Surface sediments, bacteria, archaea, microeukaryotes, high-throughput sequencing

\section{Introduction}

High-altitude and high-latitude lakes are covered by ice for more than $40 \%$ of the year. The existence of winter season affects ecology and metabolism of freshwater microorganisms. Lake Vorota is situated at the junction of Suntar-Khayata Range and Oymyakon Plateu at the altitude of $1014 \mathrm{~m}$, near the Northern Pole of Cold (Rusanov et al., 1967; Atlas..., 1989). Microscopy has shown that a photic layer of this lake is inhabited in summer by five divisions of microalgae: Cyanoprokaryota, Cryptophyta, Chrysophyta, Bacillariophyta, and Chlorophyta (Tomberg et al., 2017). Electron microscopy has allowed detecting a high diversity of silica-scaled chrysophytes (Bessudova et al., 2019), as well as a diatom Lindavia minuta (Skvortzow) T. Nakov et al. (Usoltseva et al., 2020) which was previously thought to be an endemic of Lake Baikal. These three papers are all that was published about the algae of this lake, and information about its bacterial and archaeal communities is altogether absent.

The goal of this work was to study the taxonomic composition of bacterial, archaeal and microeukaryotic communities of upper sediment in oligotrophic Lake Vorota using high-throughput sequencing

\section{Material and methods}

Samples were taken in ice period (June, 2017) in littoral zone of Lake Vorota (Yakutia) from a depth of $5 \mathrm{~m}$. The sample of surface sediment was taken by scuba divers in sterile flask and stored. Total DNA was extracted according to the standard method (Shubenkova et al., 2005). To determine the taxonomic structure, V3-V4 fragments of 16S rRNA gene of bacteria and archaea, and V4 fragment of 18S rRNA gene of eukaryotes were amplified and sequenced on Illumina MiSeq system in Evrogen (Moscow). Analysis of obtained data was performed in Usearch v. 10 (Edgar, 2010) and Mothur 1.44.2. Reads were clustered into operational taxonomic units (OTUs) at $97 \%$ gene similarity using Silva v.138.

\section{Results}

The sequencing has produced 74490 bacterial reads clustered into 974 OTUs; 61505 archaeal reads clustered into 167 OTUs; and 78835 eukaryotic reads clustered into 384 OTUs. In the sediment surface sample from Lake Vorota the highest number of reads (25\% of the library) was assigned to phylum Proteobacteria. Numerous OTUs belonged to Crenothrix, Methylibium, Steroidobacteraceae, Comamonadaceae, and Sutterellaceae. Phylum Cyanobacteria covered 23\% of the reads, including such genera as Cyanobium, Synechocystis, and Geminocystis. Phyla Bacteroidota and Desulfobacteriota made up $13 \%$ of the library each; Chloroflexi and Actinobacteriota - 10\% each; Verrucomicrobiota - 7\%; Acidobacteriota - 6\%; Spirochaeota - 3\%; Gemmatimonadota - 2\% (Fig.).

*Corresponding author.

E-mail address: maria.bashenkhaeva@gmail.com (M.V.

(C) Author(s) 2020. This work is distributed under Bashenkhaeva)

the Creative Commons Attribution 4.0 License. 
A

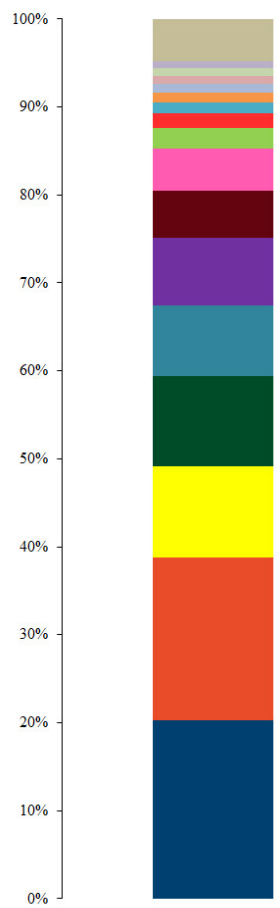

B

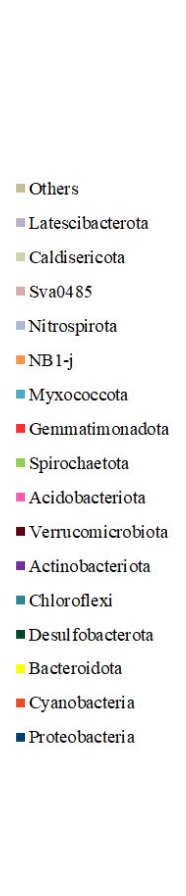

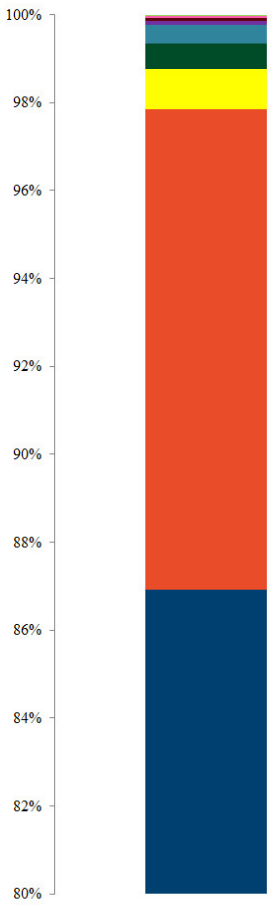

C

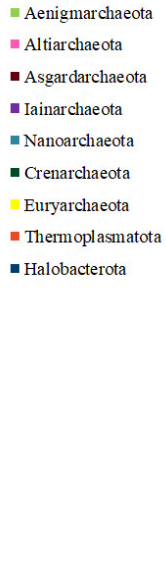

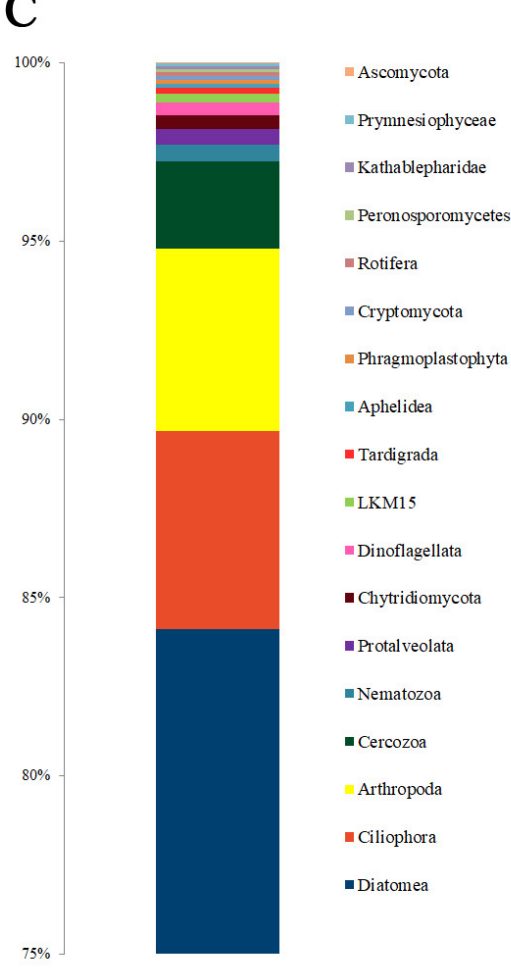

Fig. Taxonomic composition of sediment surface community in Lake Vorota according to the high-throughput sequencing of fragments of $16 \mathrm{~S}$ and $18 \mathrm{~S}$ rRNA genes. A - bacteria; B - archaea; C - eukaryotes.

Other phyla included less than $2 \%$ reads each. Among the archaea, the majority was assigned to phylum Halobacterota (87\%), with its most common OTUs being Methanoregula and Methanosaeta. Phylum Thermoplasmatota had $11 \%$ of the reads; other phyla had less than $1 \%$ reads each. Eukaryotic community was dominated by Diatomea (84\%). Most common OTUs were representatives of Fragilariales, Staurosira, Neidium, and Navicula. Ciliophora made up 5.5\% of the library; Arthropoda - 5; Cercozoa - 2.5\%. Most numerous OTUs belonged to subclass Haptoria, subtype Intramacronucleata, and order Podocopida.

\section{Discussion and conclusions}

Analysis of high-throughput sequencing data has allowed us to document taxonomic composition of sediment surface community from Lake Vorota. Most common bacterial genera, Crenothrix and Methylibium, are methane- and methylotrophic (Nakatsu et al., 2006; Oswald et al., 2017). Methanoregula, which are most common among archaea, are strictly anaerobic methanogens (Zinder and Bräuer, 2015). Diatom genera Staurosira, Neidium, and Navicula, as well as order Fragilariales, are benthic dwellers of the Arctic (Schmidt et al., 2004; Paull et al., 2008), as well as cold oligotrophic lakes such as lake Baikal (Pomazkina and Rodionova, 2003).

\section{Acknowledgements}

The authors acknowledge A.A. Dolzhenkov, the Chairman and the member of the Oymyakon Department of the Russian Geographical Society in the
Sakha (Yakutia) Republic, and the divers A.S. Gubin and S.V. Bulochkin for their assistance during the field studies. The reported study was funded by projects No. 0345-2019-0001 of the Limnological Institute of the Siberian Branch of the Russian Academy of Sciences SB RAS and No. 0376-2019-0003 of the Institute for Biological Problems of Cryolithozone SB RAS.

\section{References}

Atlas sel'skogo khozyaystva Yakutskoy ASSR [Atlas of the agriculture of Yakut Autonomous Soviet Socialist Republic]. 1989. In: Matveev I.A. (Ed.). Moscow: Main Administration of geodesy and cartography under the Council of Ministers of the USSR. (in Russian)

Bessudova A.Yu., Tomberg I.V., Firsova A.D. et al. 2019. Silica-scaled chrysophytes in lakes Labynkyr and Vorota of the Sakha (Yakutia) Republic, Russia. Nova Hedwigia, Beiheft 148: 35-48. DOI: 10.1127/nova-suppl/2019/049

Edgar R.C. 2010. Search and clustering orders of magnitude faster than BLAST. Bioinformatics 26: 2460-2461. DOI: 10.1093/bioinformatics/btq461

Nakatsu C.H., Hristova K., Hanada S. et al. 2006. Methylibium petroleiphilum gen. nov., sp. nov., a novel methyl tert-butyl ether-degrading methylotroph of the Betaproteobacteria. International Journal of Systematic and Evolutionary Microbiology 56: 983-989. DOI: 10.1099/ ijs.0.63524-0

Oswald K., Graf J.S., Littmann S. et al. 2017. Crenothrix are major methane consumers in stratified lakes. The International Society for Microbial Ecology Journal 11: 21242140. DOI: 10.1038/ismej.2017.77

Paull T.M., Hamilton P.B., Gajewski K. et al. 2008. Numerical analysis of small Arctic diatoms (Bacillariophyceae) representing the Staurosira and Staurosirella species complexes. Phycologia 47: 213-224. DOI: 10.2216/07-17.1 
Pomazkina G.V., Rodionova E.V. 2003. Benthic Bacillariophyta in Southern Baikal. International Journal on Algae 5: 29-40. DOI: 10.1615/InterJAlgae.v5.i4.30

Rusanov B.S., Bordenkova Z.F., Goncharov V.F. 1967. Geomorfologiya Vostochnoy Yakutii [Geomorphology of Eastern Yakutia]. Yakutsk: Yakutknigoizdat. (in Russian)

Schmidt R., Kamenik C., Lange-Bertalot H. et al. 2004. Fragilaria and Staurosira (Bacillariophyceae) from sediment surfaces of 40 lakes in the Austrian Alps in relation to environmental variables, and their potential for palaeoclimatology. The Journal of Limnology 63: 171-189. DOI: $10.4081 /$ jlimnol.2004.171

Shubenkova O.V., Zemskaya T.I., Chernitsyna S.M. et al. 2005. The first results of an investigation into the phylogenetic diversity of microorganisms in Southern Baikal sediments in the region of subsurface discharge of methane hydrates. Microbiology (Mikrobiologiya) 74: 314-320. DOI: 10.1007/s11021-005-0069-9

Tomberg I.V., Kopyrina L.I., Bessudova A.Yu. et al. 2017. Hydrochemistry and phytoplankton of the Lake Labynkyr and Lake Vorota (Sakha Republic). In: International conference "Lakes of Eurasia: problems and paths of their decision", pp. 426-432. (in Russian)

Usoltseva M., Kopyrina L., Titova L. et al. 2020. Finding of a putative Lake Baikal endemic, Lindavia minuta, in distant lakes near the Arctic pole in Yakutia (Russia). Diatom Research 35: 141-153. DOI: 10.1080/0269249X.2020.1747551

Zinder S., Bräuer S. 2015. Methanoregula. In: Whitman W.B. (Ed.), Bergey's Manual of Systematics of Archaea and Bacteria. New-York, pp. 1-8. DOI: 10.1002/9781118960608 